Interview

\title{
INTERVIEW WITH C.B. MACPHERSON ON THE COVID-19 PANDEMIC'
}

\section{FRANK CUNNINGHAM}

In 1983 (on the Centenary of Karl Marx's death) the Canadian Society for Socialist Studies enlisted me to interview C.B. Macpherson about the continuing significance of Marx's theories, ${ }^{2}$ and it has occurred that I might interview him again now about the relevance of his own views to the social and political ramifications of the current epidemic. A problem is that Macpherson died a few years after the earlier interview. However, luckily and likely in virtue of a just published book by me on his political thought, ${ }^{3}$ Macpherson's ghost has agreed to the interview that follows.

\section{fc Thank you Professor Macpherson for agreeing to this interview.}

cbm My pleasure, Frank, and please do call me Brough. My demise some 33 years ago does not dictate formality.

fc Thanks. My first question is what, if anything, you see as of paramount significance in the Covid-19 epidemic from the point of view of political theory and practice.

cbm Well, if anything good has come of this terrible assault on world health it is that what is now called neoliberalism is on the run. It is currently all-too-apparent that its core thesis that government regulation, provision of vital services, and in general involvement in public affairs should be kept to the minimum or eliminated altogether is deeply flawed.

I do think that public scepticism about this neoliberal tenet will stick after the pandemic is past. The need for government regulation, provision of social services, etc. and the ill effects of weakened governments to meet the crisis are too glaring, painful, and, indeed, deadly to be forgotten any time soon. I'm also hopeful that the full perspective in which the neoliberal antigovernment thesis is embedded will also be under stress.

\section{fc What perspective have you in mind?}

cbm I mean one where: 
Subjectivistic calculation of self-interest displaces moral criteria in guiding human actions.

An ethic of acquisitiveness, that is, an aspiration for unlimited accumulation of goods, is an overriding human motivation.

Economic markets permeate all aspects of life creating what Karl Polanyi called a "market society" where private property is sacrosanct and nearly everything is commodified.

Political decisions are appropriately made mainly by competition among economic elite-supported political parties.

These elements of a neoliberal perspective may have more staying power than just its antipathy to government. But to the extent that the connections between the attack on government and these other features can be shown (here, I think, is a task for political theorists) the entire perspective might lose credibility in the public mind.

Could I make a terminological comment? I, myself, did not use term neoliberalism. Though I came at the phenomenon in criticizing Milton Friedman. ${ }^{4}$ However, I have a misgiving about this term. I would prefer that it be called "perverse" or "distorted" liberalism. Liberalism in the early, $17^{\text {th }}$ Century extolled "the value and rights of the individual," and it was only in the hands of such as Hobbes, Locke and later Bentham and the Schumpetarian political-scientific "Realists" that it came to take on its further market society-sustaining meaning. My effort was therefore not to reject individualism, but to "repair" what I saw as "a perversion of the fundamental liberal insights of an earlier tradition."6

fc Someone might agree that the crisis challenges neoliberal celebration of the minimal state but question your endorsement of individualism. Does not this crisis show the importance of retrieving the values of community and cooperation?

cbm Yes it certainly does, but one must question what the essential characteristics are of the humans who inhabit communities and who can cooperate. Central to my thinking is that in modern times there have been two, competing conceptions of human nature. From a "possessiveindividualist" viewpoint:

The human essence is freedom from any relations other than those a man enters with a view to his own interest.... The individual is proprietor of his whole person, for which he owes nothing to society. He is free to alienate his capacity of labour... 
Society is a series of relations between proprietors. ${ }^{7}$ [And, the individual is] an infinite appropriator and an infinite consumer. ${ }^{8}$

The competing conception, which I call "developmental democratic" or which Alasdair MacIntyre thought should be called "cooperative and creative individualism" (this is alright with me) is based, as I put it, “on a view of man's essence not as a consumer of utilities but as a doer, a creator, an enjoyer of his human attributes." ${ }^{10}$ I give a sample list of what these essentially human attributes are:

They may be taken to include the capacity for rational understanding, for moral judgement and action, for aesthetic creation and or contemplation for the emotional activities of friendship and love, and, sometimes, for religious experience. Whatever the uniquely human attributes are taken to be ... their exertion and development are seen as ends in themselves, a satisfaction in themselves, not simply a means to consumer satisfaction. ${ }^{11}$

fc Excuse me for interrupting your important point here, Brough, but I note in your quoted descriptions you use gendered pronouns. I take it by "man" and "his" you mean "human" and “a person's."

cbm You know very well, Frank, that this is what I mean, and from my 1977 book, The Life and Times of Liberal Democracy, I corrected my language in this regard. My wife of 44 years, Kay, was too occupied with ground-level politics - in the Canadian peace and the women's movements where she was an important feminist leader - to get around to reading my academic prose or I'm sure she would have set me straight from the beginning.

fc Thanks, Brough, and sorry (sort of) for my rude interruption. I don't know if ghosts can access books published post mortem, but Kay's account in 1994 of her political and family life alludes to what you just reported. ${ }^{12}$ To return to the main interview, could you explain how your two conceptions of human nature relate to communalism and cooperation and to the Covid-19 epidemic?

cbm The democratic-developmental conception is inherently community friendly and cooperative. It rejects what Charles Taylor criticizes as an "atomistic" viewpoint. ${ }^{13}$ Like Taylor, Marx, and others, I see human capacities as socially derived and regard society as "the medium through which human capacities are developed." 14 By contrast with a possessive-individualist conception, a developmental one "brings with it a sense of community": 
One can acquire and consume for one's own satisfaction or to show one's superiority to others.... Whereas the enjoyment and development of one's capacities is to be done for the most part in conjunction with others, in some relation of community. ${ }^{15}$

This is obviously the case with such capacities as for love and friendship, and cooperative values also enter into the identification of such capacities. Whatever these are taken to be, they have in common that their use "by each member of a society does not prevent other members from exercising theirs." 16 That is, they do not involve ineradicable competition but on the contrary typically require cooperation for their development and use.

\section{fc And this pertains to lessons learned from the Corona-19 virus crisis, how?}

cbm By relation to one's conception of a good society. A society informed by a developmentaldemocratic conception is one where people are equally possessed of the resources and the opportunities fully to develop their potentials - that is, the truly human potentials that I just described. A possessive-individualist society, geared as it is to limitless consumption and marked by competition for profits or for jobs is incompatible with this vision.

A developmental-democratic society, as I explained in the 1983 interview you conducted, responds to demands of social movements "concerned more with the quality of life than with the quantity of consumables," 17 and it includes participation in the work place where the aim of working people "to make their productive work more meaningful" is realized. ${ }^{18}$ By contrast, the worth of a possessive-individualist society is measured by the extent to which individuals can satisfy consumerist demands and by increase of what used to be called the Gross National Product (now Gross Domestic Product) considered to be "the supreme goal of national policy."19

I described the opposed images of a good society implicated in these conceptions in order to advocate the developmental-democratic one and to identify inhibitors to achieving it. Main inhibitors I discussed were scarcity, including the artificial scarcity bred of consumerism, and the precarious, ill-remunerated and largely unsatisfying quality of work in a capitalist market society.

Pandemics (which I never addressed), like environmental degradation (which I did address), exhibit other inhibitions to achieving a developmental-democratic society. In each case capitalist market societies lack the resources to confront the crises. Worse, they exacerbate them by treating health and the environment (like about everything else) as private property, rather than as resources over which people should be trustees for present and future generations. ${ }^{20}$

\section{fc So you see the effects of the pandemic and reactions to it as evidence in favour of your social and political views.}


cbm Yes, these do lend weight to the views I expressed especially about the ill effects of possessive individualism and prospects for loosening its grip on popular consciousness.

From a political-economic point of view, possessive individualism naturally tends toward neoliberal attacks on government. Also, though some defend social distancing and other sacrifices on the grounds just of individual self interest, most political leaders, policy advocates, and pundits, including many conservatives, now emphasize the interdependence of people and the need for mutual aid and cooperation as an ethical and not just a prudential matter. Front line health-care and other essential service workers are praised precisely for risks they take for the common good.

I could continue adducing evidence for my theories, but if it's alright with you I'd rather indicate how they relate to the current crisis and possible reactions to it on the assumption that these theories can be supported.

\section{fc Please do.}

cbm I think that three of my theories have relevance to debates and discussion that you (the still living) are starting to engage in and that will surely accelerate. One of these concerns is taking advantage of state powers to reorganize a nation's economy which will require prying them away from subservience to the needs of capitalism.

\section{fc Do you mean securing social ownership of the means of production?}

cbm As you know, since you emphasize it in your book on my thinking (I can access publications post-mortem), for the most part I abstained from making specific institutional recommendations, leaving this for those with appropriate expertise. I confined myself to maintaining that a fully democratic society would require "democratic political control over the uses to which the amassed capital and the remaining natural resources are put" and that "it probably does not matter whether this takes the form of social ownership of all capital, or a social control of it so thorough as to be virtually the same as ownership." ${ }^{11}$

Appealing to writings by neo-Marxists, including Ralph Miliband, James O'Connor, and Jürgen Habermas, who challenged a stream of Marxist thinking that left no room for state comportment independent of capitalism, ${ }^{22}$ I concluded that the state has been "moving away from being a mere superstructure and to having attained a significant degree of autonomy." Though governments today still serve core needs of a capitalism economy, they have also provided cushions against unemployment, old age and health costs, protected against unemployment, engaged in infrastructure, educational, and public housing reforms, initiated policies for environmental protection, and taken other such measures. ${ }^{23}$

I also described forces in society to whose demands states must be attentive if they are to retain legitimacy. These include the personnel of the public sector, recipients of welfare benefits, and the organized part of the labour force. Such a state can also justify itself to a critical mass of 
capitalists in the way that the New Deal was accepted by them, and thanks to the fragmentation of capitalism not all its segments need be accommodated. ${ }^{24}$ I flagged as "the central problem of the advanced capitalist state" the danger that "capital can go on strike" against robust reforms by a (relatively) autonomous state, but I opined that this danger would likely be averted. ${ }^{25}$

These speculations were written in 1977, that is, two years before the election of Thatcher and four before that of Reagan, and my optimism then was evidently unjustified. However, now states all over the world are intervening in public affairs and pursuing economic policies beyond the worst nightmares of the neoliberals.

\section{fc Might not the degree of autonomy from capitalist interests necessitated by current circumstances wane post the Covid-19 crisis?}

cbm Of course one cannot rule this out. But working against it is that attacks on state regulations and provision of public goods were already being resisted before the crisis as in social-movement activism against inequalities and for protection of the environment. Also relevant is my view that the staying power of capitalistic and other institutions that are informed by possessive individualism depends on the fatalistic assumption that acceding to them is inevitable. The state interventions now being undertaken, however prompted, provide evidence against such fatalism. I might have cited Kant's obviously correct dictum that "everything actual is possible."

\section{fc You said that there are three components of your theories that emerge from reflections on the pandemic.}

cbm Yes, a second component has to do with the quality of work. As already mentioned developmental democracy is aimed at enhancing the quality of people's lives rather than at indefinite production of consumer goods. And when I discussed the prospects for achieving industrial democracy I argued that this depends in part on workers" "changing their priorities from consumer satisfaction to work gratification. ${ }^{27}$ I stand by these views and think that the current crisis does reinforce aspirations not just for adequate remuneration but for reforming the nature of work to make it intrinsically rewarding. We tenured professors forget that we are in a small and privileged category of employees whose work is of this sort.

\section{fc But Brough, there are examples of possessive-individualist professors who scheme to get more income than they need for a secure and comfortable livelihood.}

cbm To be sure there are some academics of this ilk, and maybe more than in my day thanks to penetration of neoliberalism into university governance and culture. However, is it not the case that most in the current generation of academics, like colleagues in mine, would not trade their work as teachers and researchers for the much more lucrative incomes that could be garnered in 
some other professions? My point is not that professors are a unique breed, but to exemplify the claim that people are not possessive individualists as a result of their human nature and that, given the all-too-rare opportunity, they choose work that enhances the quality of their lives, including their work lives.

Workers' Cooperatives (some of which still exist in Northern Europe and in the Spanish Basque country) typically assign a higher priority to their members' working conditions than to salary levels, and "social" as opposed to "business" unions also exhibit this prioritization. The Covid-19 pandemic has dramatically exposed the poor wages for the most essential of workers, as for example, those in hospitals and long-term care facilities, and some governments are pledging not just to rectify this situation, but to improve the quality of their work as well.

I note that the policy of your (my?) Prime Minister economically to compensate for layoffs resulting from the pandemic has elicited charges by some conservatives that this will prompt these workers to stay on the dole after the pandemic has passed. In addition to raising minimum wages, a way to forestall this temptation is to ensure not just that people have well paying jobs to return to but that these are satisfying jobs.

\section{fc On this point, Brough, I can call your attention to an op-ed I recently received prepared by an international group of political scientists soliciting signatures:}

The people who have kept life going through the COVID-19 pandemic are living proof that work cannot be reduced to a mere commodity. Human health and the care of the most vulnerable cannot be governed by market forces alone... [And work needs now to be decommodified] to allow us to ensure the dignity of all citizens while marshalling the collective strength and effort we need to preserve our life together on this planet. $^{28}$

cbm Thanks for calling this to my attention. I'd ask you to have my name added to this document, but that would be considered puzzling if not eerie.

\section{fc Indeed. Can we turn to the third component of your theories that has a bearing on the crisis?}

cbm Contrary to those who see democracy as just protecting citizens against the worst excesses of capitalist-serving governments ("protective democracy") or as providing forums where representatives of mainly intra capitalist groups can negotiate terms of joint governance ("equilibrium democracy"), the developmental democracy I advocate centrally includes bottomup citizen input, that is "participatory democracy." ${ }^{29}$ I speculated that a pyramidal governmental system might be made to work for this purpose, ${ }^{30}$ but short of such radial transformation there can be provision for popular input to government by inclusion of citizens in commissions and boards 
combined with delegation of some decision-making powers to local-level citizen groups as proposed by advocates of the theory now called Associative Democracy.

Unlike in the case of discarding minimal state policies and highlighting a need for the reform of work, reactions to the Covid-19 crisis have so far not prompted much citizen activism. The media largely focus on two modes of governance - authoritarianism, whether of the Chinese variety or Trump's populist version, and more democratically responsible heads of state trying to reconcile conflicting public pressures. There is sometimes coverage of nurses' unions and organizations of care-facility workers that has vividly described dangerous conditions in healthcare facilities and documented the effects of privatization and deregulation. Less acknowledged are ways that neighbourhood groups, associations of small business, and others have taken their own measures to survive the epidemic.

One prerequisite for achieving more participatory democracy is getting established political parties out of the way of citizen activism. While I acknowledged some indispensable roles that political parties play in democratic governance, I saw them currently as blurring class lines and creating the illusion of citizen input to government while shutting off access to it for most people. ${ }^{31}$ Just as the need for state regulation is made evident in the current circumstances, so is this inhibition to citizen participation.

Perhaps the shortcomings of both dictatorial politics and dependence on the accident of a jurisdiction having a responsible political leader may contribute to citizens themselves marshaling resources to combat the virus and rebuilding their societies afterward. This could include looking to channels for direct input to governance or at least finding ways to force those political parties that are not part of the elite consortium of capitalist-serving ones (I would like to believe that some social-democratic parties are of this sort) to be more democratic both internally and with respect to citizen responsiveness.

\section{fc Do you see a role for social media and electronic communication in facilitating participatory democracy?}

cbm In The Life and Times I addressed proposals for electronic voting and referenda, and I expressed scepticism about how far this could advance bottom-up democracy. ${ }^{32}$ I still question the opinion that participatory democracy can simply be technologically achieved. However, electronic technology has advanced so far since my time that it can significantly enhance citizen participation by facilitating communication among the members of social movements and citizen organizations. So, yes, I do now see a role for this technology in these regards.

fc One can certainly share your hope regarding the prospects for participatory democracy, as well as for independent, progressive state action and the transformation of work. I take it that you see reactions to some features of the Covid-19 crisis as offering grounds for such hope. 
cbm This topic comes down to the question of whether one can expect a large-scale change in popular consciousness away from fatalistic accommodation to possessive-individualistic policies and institutions. In The Life and Times I described conditions that opened "loopholes" in such accommodation: "The increasing awareness of the costs of economic growth, the increasing awareness of the costs of political apathy, the increasing doubts about the ability of corporate capitalism to meet consumer expectations while reproducing inequality." ${ }^{33}$ These loopholes still exist.

fc One contributor to fatalism has been doubt that developmental democracy can be afforded, and in the current circumstances won't such doubt be reinforced? Will not massive postpandemic increases in GDP, reduction in costs to private enterprises by wage reductions, increased use and sale of environmentally destructive resources, and other such measures be needed to cover current government expenditures?

cbm I do not dismiss such considerations, though their force partly depends upon amnesia. Those of my generation can remember periods of time in Canada, as in the U.S. and Europe, when much more in the way of social services was provided than later, when costs of education and health care were lower, and when wages were higher.

The distribution of wealth should also be taken into account. The national inequalities I had in mind in the 1970s were less than today, where, as focused on by the anti-1\% movements, people struggling to afford food and shelter co-exist not just with millionaires, but now with billionaires, who, moreover, easily dodge taxation just as corporations enjoy tax havens and government bail outs. The current annual military expenditures of 25 countries is over 1.7 trillion US dollars. (Canada, at $\$ 22.5$ billion, ranks $16^{\text {th }}$, the U.S. is $1^{\text {st }}$ at $\$ 750$ billion, followed by China at $\$ 237$ billion). ${ }^{34}$

Finally, it should be observed that a society aimed at enabling its citizens to develop their humanistic potentials is less expensive than is a possessive-individualistic society geared to limitless consumption and ever-increasing economic growth. I don't mean to suggest that economic problems during and after the Covid-19 crisis are not real, but to deny that they can only be addressed if the "normal" we are to return to is that of a market society.

fc So do you predict that the crisis will precipitate a revolution in popular consciousness with attendant political pressures sufficient to emerge from the Covid-19 pandemic in a way that transforms our society in a developmental-democratic direction?

cbm Well Frank, I wish I could be at least as optimistic now as I was several decades ago. Then I was largely worried about the cooptation of progressive programmes by welfare capitalism. Though I did not rule out resurgence of the sort of "corporatist plebiscitarian state" I wrote about 
in my first book (on Social Credit in Alberta), ${ }^{35} \mathrm{I}$ did not anticipate the strength, pervasiveness, and brutality of the current right wing populism you confront today.

Also my powers of political-scientific prediction were not exactly stellar when I was alive and I have no reason to think that they have strengthened since. But I still hold that possessive individualism flies in the face of human nature and that conditions exist for challenging it, some of which are thrown into relief by the Covid-19 crisis. I'm inclined to offer you not a prophesy, but, as I put it regarding participatory democracy, "a glimpse of possibilities."

\section{fc Many thanks for this interview. I'm sorry that we must, again, part ways.}

\footnotetext{
${ }^{1}$ Conducted in Vancouver, May 2020. Thanks to Nickolas Blomley, Jamie Lawson, Ian McKay, and Philip Resnick
} for helpful suggestions.

${ }^{2}$ C.B. Macpherson, "Interview on the Centenary of Marx's Death” Socialist Studies Annual '83 (Winnipeg: University of Manitoba Publication, 1983) 7-12. This interview was paired with one on the same topic with the Marxist historian of Canada, Stanley Ryerson. The Macpherson interview is reproduced in Frank Cunningham, The Real World of Democracy Revisited (Atlantic Highlands, N.J.: Humanities Press, 1994) 14-21. The 1983 interview is accessible at https://socialiststudies.com/index.php/sss/article/view/27305/20214.

${ }^{3}$ Frank Cunningham, The Political Thought of C.B. Macpherson: Contemporary Challenges (New York: Palgrave, 2019).

${ }^{4}$ C.B. Macpherson, Democratic Theory: Essays in Retrieval (Oxford: Oxford University Press, 1973, reissued 2012) essay vii.

${ }^{5}$ C.B. Macpherson, The Political Theory of Possessive Individualism: Hobbes to Locke. (Oxford: Oxford University Press, 1962, reissued, 2010) 1.

${ }^{6}$ Ibid. 2.

${ }^{7}$ Ibid. 269.

${ }^{8}$ Democratic Theory 5.

9 Alasdair MacIntyre, “On 'Democratic Theory: Essays in Retrieval' by C.B. Macpherson," Canadian Journal of Philosophy, vol. 6, no. 2 (June 1976) 177-181.

${ }^{10}$ Democratic Theory 4.

${ }^{11}$ Ibid. 4-5.

${ }^{12}$ Kay Macpherson, When in Doubt Do Both: The Times of My Life (Toronto: University of Toronto Press, 1994$) 68$. 
${ }^{13}$ Charles Taylor, "Atomism" in Alkis Kontos, ed. Powers, Possessions and Freedom: Essays in Honour of C.B. Macpherson (Toronto: University of Toronto Press, 1979) 39-61.

${ }^{14}$ C.B. Macpherson, "Individualist Socialism? A reply to Levine and MacIntyre," Canadian Journal of Philosophy, vol. 6, no. 2 (June, 1976) 195-200, 199.

${ }^{15}$ C.B. Macpherson, The Life and Times of Liberal Democracy (Oxford: Oxford University Press. 1977, reissued in 2012) 99.

${ }^{16}$ Democratic Theory 54.

${ }^{17}$ Socialist Study Interview 10.

${ }^{18}$ Life and Times 104-105.

${ }^{19}$ C.B. Macpherson, "The Currency of Values," Transactions of the Royal Society of Canada (University of Toronto Archives, series 4, vol. 9, 1971) 27-35, 34 .

${ }^{20}$ Democratic Theory Essay VI.

${ }^{21}$ Life and Times 111.

${ }^{22}$ C.B. Macpherson, "Do We Need a Theory of the State" (1977), reprinted in The Rise and Fall of Economic Justice (Oxford: Oxford University Press, 1985, reissued in 2013) 61-62.

${ }^{23}$ Ibid. 65-66.

${ }^{24} \mathrm{Ibid} .68-70$.

${ }^{25}$ Ibid. 70.

${ }^{26}$ Immanuel Kant, The Critique of Pure Reason (London: Macmillan Palgrave, 2003 [1788]) 250.

${ }^{27}$ Economic Justice 40.

28 "Work: Democratize, Decommodify, Remediate," www.democratizingwork.org. The op ed is scheduled for publication in 31 countries and 36 major papers, such as Le Monde, Die Zeit, and The Guardian, and has over 3,000 signatures.

${ }^{29}$ Most fully explicated in The Life and Times.

${ }^{30}$ Ibid. 108-114.

${ }^{31}$ Ibid. see 69, 78, 112-113.

${ }^{32}$ Ibid. 95-98. 


\section{${ }^{33}$ Ibid. 106.}

34 “Global Firepower 2020 Report," https://www.globalfirepower.com/defense-spending-budget.asp

${ }^{35}$ Economic Justice 16; C.B. Macpherson, Democracy in Alberta: Social Credit and the Party System (Toronto: University of Toronto Press, 1953, reissued in 2013).

${ }^{36}$ Life and Times 108. 